\title{
PENGARUH BUDAYA, SOSIAL, PRIBADI DAN PSIKOLOGIS TERHADAP KEPUTUSAN PEMBELIAN KONSUMEN EKOWISATA
}

\author{
ANDI FAISAL BAHARI, MUHAMMAD ASHOER* \\ Fakultas Ekonomi, Universitas Muslim Indonesia, Makassar
}

\begin{abstract}
ABSTRAK: Studi ini bertujuan untuk menganalisis pengaruh budaya, sosial, pribadi, dan psikologis terhadap keputusan kunjungan wisatawan Malino Highland, Kabupaten Gowa. Populasi penelitian ialah wisatawan Malino Highland, dan teknik pengambilan sampel menggunakan purposive sampling yaitu orang yang sudah pernah mengunjungi Malino Highland. Pengumpulan data dilakukan dengan menggunakan kuisioner. Responden yang memenuhi syarat ditetapkan sebanyak 150 wisatawan yang dianalisis dengan SPSS. Hasil penelitian menunjukkan bahwa kebudayaan, sosial pribadi, dan psikologis berpengaruh secara simultan dan parsial terhadap keputusan kunjungan wisatawan Malino Higland, Gowa. Variabel psikologis merupakan variabel yang paling dominan. Temuan ini memiliki implikasi penting terhadap strategi pemasar ekowisata dalam rangka memaksimalkan penciptaan nilai bagi wisatawan.
\end{abstract}

Kata Kunci: Kebudayaan, Sosial, Pribadi, dan Psikologis, Keputusan Pembelian, Ekowisata

ABSTRACT: This study aims to analyze the effect of cultural, social, personal, and psychological on consumer decision in visiting the Malino Highland, Gowa. The population was the visitors of Malino Highland and sampling technique with purposive sampling. A questionnaire was deployed to collect the primary data. The number of respondents that meet the sampling criterion was 150 visitors. The data was measured by multiple regression analysis with SPSS software. The results show that the cultural, social, personal, and psychological affect simultaneously and partially the visitors' decision to visit the Malino Highland, Gowa. The psychological variable is the most dominant in effect. This finding is important for ecotourism marketing strategy to maximize the value creation of consumers.

Keywords: Culture, Social, Personality, Psychological, Consumer Purchasing Decision

\footnotetext{
*Surel korespondensi Penulis: faisal.bahari@umi.ac.id

ISSN-E: 2597-6990

ISSN-P: 2442-4951

http://journal.uin-alauddin.ac.id/index.php/minds
} 


\section{PENDAHULUAN}

Sektor pariwisata merupakan salah satu sektor unggulan yang diandalkan untuk meningkatkan kesejahteraan masyarakat dan pembangunan nasional (Arida, 2009). Ekowisata (ecotourism) merupakan perwujudan tersebut, dimana kegiatan wisata difokuskan pada konservasi alam dan pengembangan dan pemberdayaan sosial, budaya, dan ekonomi masyarakat setempat. Pengembangan sektor ini menuntut pemasar pada proses pengidentifikasian preferensi konsumen yang akurat agar dapat memenuhi ekspektasi (kebutuhan dan keinginan) wisatawan (Mondal, 2015). Pola perilaku konsumen secara umum dipengaruhi oleh 2 (dua) aspek, yaitu pengaruh internal dan eksternal. Isu lain yang layak dipertimbangkan ialah kepopuleran media sosial, dimana konsumen menganggap realita dunia maya menjadi referensi utama dalam keputusan pembelian (Ashur, 2016). Pemahaman faktor- faktor yang dapat memengaruhi wisatawan dalam merancang penciptaan nilai untuk konsumen sangat vital. Pemasar dapat mengembangkan industri dan memahami latar belakang yang memengaruhi seorang konsumen dalam menentukan keputusan berkunjung ke sebuah spot wisata alam, khususnya Malino Highland, Sulawesi Selatan.

Dinas Pariwisata dan Kebudayaan Kabupaten Gowa Merilis data jumlah wisatawan baik domestik maupun mancanegara yang berkunjung ke kabupaten Gowa sepanjang tahun 2017. Hasilnya sebanyak 234.706 wisatawan mengunjungi 20 objek wisata yang ada di Kabupaten Gowa. Jumlah itu terbagi antara objek wisata budaya dan sejarah, juga wisata alam dan buatan (Disbudpar Gowa, 2017).

Malino Highlands merupakan sebuah kawasan wisata alam termegah di Sulawesi Selatan yang digadang-gadang akan menjadi Landmark Dunia. Kehadirannya memberikan kesan terhadap pesona alam hijau dan menawan bagi para pengunjungnya. "Kehijauannya" ditunjukkan dengan hamparan kebun teh seluas 900 hektar, pohon pinus yang mengelilingi area wisata, dan berbagai macam tanaman/ tumbuhan hijau. Meskipun memiliki panorama yang memanjakan mata, pengembangan Malino Highland masih mengalami berbagai macam hambatan. Beberapa kendala tersebut seperti daya tarik objek wisata belum optimal dalam meningkatkan jumlah kunjungan wisatawan, belum optimalnya upaya promosi dan pemasaran dari produk wisata, stagnasi pengembangan produk pariwisata, penyediaan sarana dan prasarana objek wisata belum memadai, dan aksesibilitas transportasi masih belum memenuhi harapan konsumen. Memperkenalkan usaha jasa pariwisata dan mengembangkannya tidak serta merta dapat berlangsung dengan mudah, apalagi berbentuk wisata alam yang secara umum kurang diketahui oleh masyarakat Indonesia. Konsekuensinya, masyarakat Indonesia kurang mengetahui prospek wisata alam mereka sendiri, dan nampaknya isu ini juga dihadapi oleh beberapa negara berkembang (Cohen et. al., 2013).

Pembelian konsumen di pengaruhi oleh banyak hal seperti rangsangan pemasaran, rangsangan lain, psikologis, karakteristik konsumen, proses sebelum melakukan keputusan pembelian hingga konsumen memutuskan pembelian dan hingga pembelian itu selesai akan berpengaruh pada pembelian 
lainnya. Beberapa penelitian untuk mengetahui pengaruh faktor kebudayaan, sosial, budaya dan psikologis konsumen dalam melakukan keputusan pembelian telah dilakukan oleh Mas Oetarjo tahun 2013, dari Variabel bebas yang diteliti yang terdiri dari faktor budaya, sosial, individu dan psikologis secara simultan dan parsial mempunyai pengaruh yang signifikan terhadap minat berkunjung ke tempat wisata bahari Lamongan. Imam Ahmad Adhi tahun 2016, dari hasil pengujian diperoleh faktor psikologis mempunyai pengaruh yang signifikan secara simultan terhadap keputusan berkunjung wisatawan Batu Secret Zoo Jawa Timur Park 2. Mengingat berbagai masalah tersebut, wisata alam menjadi relevan untuk dikembangkan karena perannya sebagai pengingat akan keindahan alam yang ada di Indonesia, khususnya Sulawesi Selatan.

Oleh karena itu seorang pemasar harus memahami pengaruh kebudayaan, sosial, pribadi dan psikologis konsumen yang menjadi segmennya agar dapat menarik kunjungan wisatawan, menciptakan kepuasan konsumen dan loyalitas konsumennya. Menurut Kotler dan Armstrong (2012), Kebudayaan sendiri terdiri dari budaya, sub budaya dan kelas sosial. Sosial terdiri dari kelompok referensi, keluarga, peran dan status. Pribadi terdiri dari usia dan tahap siklus hidup, pekerjaan, situasi ekonomi, gaya hidup, serta kepribadian dan konsep diri. Sedangkan, psikologis terdiri dari motivasi, persepsi, pembelajaran, kepercayaan dan sikap.

TINJAUAN PUSTAKA

\section{Ekowisata (Ecotourism)}

Ekowisata merupakan jenis wisata yang hadir untuk menjawab kebutuhan masyarakat akan liburan yang jauh dari keramaian (mass-tourism). Secara utuh, Diamantis (2004) mengemukakan bahwa ekowisata dapat dipandang sebagai konsep sustainability, yang terdiri dari sub-komponen wisata alternatif dan wisata berbasis alam. Masyarakat Ekowisata Internasional atau TIES (The International Esotourism Society) mendefinisikan ekowisata sebagai perjalanan wisata alam yang bertanggungjawab dengan cara melakukan konservasi lingkungan dan meningkatkan kesejahteraan masyarakat lokal (responsible travel to natural areathat conserves the environment and improves the well-being of local people (TIES dalam Arida, 2009). Ekowisata dapat dilihat dari tiga perspektif, yakni pertama ekowisata sebagai produk, merupakan semua atraksi yang berbasis pada sumberdaya alam. Kedua ekowisata sebagai pasar, merupakan perjalanan yang diarahkan pada upaya-upaya pelestarian lingkungan. Ketiga, ekowisata sebagai pendekatan pengembangan, artinya ekowisata merupakan metode pemanfaatan dan pengelolaan sumberdaya pariwisata secara ramah lingkungan (Arida, 2009).

\section{Perilaku Pembelian Konsumen/ Wisatawan}

Pemahaman terhadap kebutuhan dan keinginan konsumen merupakan objek vital dalam memprediksi perilaku. Mengetahui bagaimana perubahan respon serta feedback yang terjadi pada diri konsumen bergantung pada dua hal; pertama, mengenai pengaruh dari karakteristik konsumen dalam menerima suatu stimulus dari seorang pemasar; kedua, bagaimana keputusan pembelian dipengaruhi oleh perilaku konsumen itu sendiri (Kotler dan Keller, 2012). Beberapa faktor penting yang memotivasi keputusan pembelian konsumen ialah budaya, sosial, pribadi dan psikologis (Kotler dan Keller, 2012). Faktor kebudayaan, sosial, pribadi dan psikologis dasar memainkan peranan penting 
dalam memahami bagaimana konsumen benar-benar membuat keputusan pembelian mereka. Perusahaan yang cerdas berusaha untuk memahami proses keputusan pembelian pelanggan secara penuh, semua pengalaman mereka dalam pembelajaran, memilih menggunakan, dan bahkan menyingkirkan produk. Ke-empat variabel tersebut tidak dapat dikontrol oleh serangkaian strategi pemasaran, namun pemasar dapat memprediksi dan kemudian mengintervensi faktor-faktor tersebut untuk merangsang pembelian.

Dalam penelitian ini, keputusan berkunjung wisatawan menjadi keputusan pembelian atau objek penelitian. Menurut Solomon (dalam Correia dan Crouch, 2008:122), perilaku wisatawan adalah proses yang melibatkan kegiatan pemilihan, pembelian, penggunaan, atau penentuan barang, jasa, gagasan atau pengalaman seseorang atau kelompok untuk memenuhi kebutuhan perjalanan mereka. Sedangkan Morrison (2008:75) mendefinisikan bahwa, perilaku wisatawan adalah cara memilih bagi wisatawan, ketika mereka menggunakan dan bertindak setelah membeli barang dan jasa wisata dan jasa perjalanan. Definisi di atas menggambarkan bahwa wisatawan sebagai konsumen juga dipengaruhi oleh produk/jasa yang ditawarkan oleh situs ekowisata tertentu. Dengan kata lain, proses pengambilan keputusan untuk mengunjungi tempat ekowisata ditunjang oleh pengalaman wisatawan, sarana dan prasarana, serta penunjang yang dapat memuaskan kebutuhan wisata alam konsumen. Ini menunjukkan peran penting customer relationship dan yang tidak bisa dilupakan adalah sosial media dalam menjaring pelanggan (Rahman \& Taning, 2015; Rahman, 2016).

Faktor Budaya

Budaya memainkan peran penting dan mendalam dalam pembentukan perilaku pembelian konsumen. Kotler dan Armstrong (2012) mendefinisikan kebudayaan sebagai seperangkat nilai-nilai, kepercayaan, kebiasaan, keinginan dan perilaku yang dipelajari oleh masyarakat sekitar, dari keluarga, atau lembaga formal lainnya sebagai sebuah pedoman perilaku. Aspek eksernal ini menjadi faktor penentu yang paling mendasar dari segi keinginan dan perilaku seseorang karena menyangkut segala aspek kehidupan manusia. Dalam faktor kebudayaan, pemasar harus memahami pengaruhnya terhapap konsumen yang meliputi budaya, subbudaya dan kelas sosial.

Faktor Sosial

Faktor sosial merupakan pengaruh dari sekelompok orang yang memengaruhi seorang individu untuk mengikuti kebiasaannya. Faktor sosial seperti kelompok sosial, keluarga, serta peranan dan status social merupakan aspek eksternal yang menstimulasi keputusan pembelian konsumen (Kotler dan Keller, 2012). Kelompok acuan, kelompok acuan seseorang terdiri dari semua kelompok yang memiliki pengaruh langsung atau tidak langsung terhadap sikap atau perilaku seseorang. Keluarga, keluarga merupakan organisasi pembelian konsumen yang paling penting dalam masyarakat dan ia telah menjadi obyek penelitian yang luas. Anggota keluarga merupakan kelompok acuan primer yang paling berpengaruh. Pengaruh yang lebih langsung terhadap perilaku pembelian sehari-hari adalah keluarga prokreasi yaitu pasangan dan anak-anak. Peran dan status, peran meliputi kegiatan yang diharapkan akan dilakukan oleh seseoang. masing-masing peran menghasilkan status. Mondal (2015) menyatakan bahwa pertimbangan pemasar dalam 
menyesuaikan kebutuhan dan keinginan wisatawan yang cocok untuk tiap-tiap unit dalam kelompok sosial sangat vital untuk menciptakan strategi pariwisata yang efektif.

Faktor Pribadi

Keputusan pembelian konsumen terbentuk oleh berbagai macam ciri-ciri dan sifat yang ada di dalam diri seseorang. Menurut Kotler dan Keller (2012) "Keputusan pembelian juga dipengaruhi dari karakteristik seorang individu, seperti usia dan tahap siklus hidup, pekerjaan, situasi ekonomi, gaya hidup, serta kepribadian dan konsep diri". Faktor pribadi merupakan cara mengumpulkan dan mengelompokkan kekonsistenan reaksi seorang individu terhadap situasi yang sedang terjadi (Omondi, 2017). Perilaku wisatawan ketika memutuskan untuk berkunjung ke tempat wisata juga tidak dapat dilepaskan dari faktor-faktor kepribadian yang bersangkutan. Faktor tersebut menggabungkan antara tatanan psikologis dan pengaruh lingkungan wisatawan untuk menikmati aktivitas liburan yang mereka telah tentukan.

Faktor Psikologis

Sikap, perasaan, persepsi, dan perilaku individu yang diperoleh dari pengalaman subyektif seseorang disebut psikologis. Dalam proses keputusan pembelian, peneliti secara umum membagi empat faktor internal yang memengaruhi konsumen yaitu motivasi, persepsi, pembelajaran, serta kepercayaan dan sikap (Kotler dan Keller, 2012; Durmaz, 2014). Motivasi merupakan suatu penggerak atau dorongan dalam diri seseorang untuk melakukan dan mencapai suatu tujuan. Seseorang memiliki banyak kebutuhan pada waktu tertentu. Persepsi adalah proses yang digunakan oleh konsumen untuk memilih, mengorganisasi, dan menginterprestasikan informasi guna menciptakan gambaran dunia yang memiliki arti. Berikutnya, perubahan perilaku konsumen yang timbul dari pengalamannya, sehingga saat konsumen bertindak pengetahuannya pun akan bertambah disebut pembelajaran. Keyakinan (belief) adalah gambaran pemikiran yang dianut konsumen tentang suatu hal. Terakhir, sikap (attitude) adalah evaluasi, perasaan emosional, dan kecenderungan tindakan yang menguntungkan atau tidak menguntungkan serta bertahan lama dari seseorang terhadap suatu obyek atau gagasan.

\section{Pengembangan Kerangka Konseptual dan Hipotesis Penelitian}

Faktor-faktor yang mempengaruhi keputusan pembelian konsumen adalah rangsangan pemasaran, psikologi, dan karakteristik konsumen yang akan memengaruhi proses keputusan pembelian dan melanjutkan pada keputusan pembelian Kotler dan Keller (2009). Menurut Kotler dan Armstrong (2012) menyatakan bahwa hal-hal yang mempengaruhi keputusan pembelian konsumen adalah faktor kebudayaan, sosisal, pribadi dan psikologis. Beberapa penelitian terdahulu yang dilakukan menunjukan adanya hubungan antara variabel pada Gambar 1. Berdasarkan Gambar 1 menunjukan adanya 4 variabel bebas $(X)$ yang mempengaruhi variabel terikat $(Y)$, yaitu pengaruh variabel budaya $\left(X_{1}\right)$, sosial $\left(X_{2}\right)$, pribadi $\left(X_{3}\right)$, dan psikologis (X4) yang memengaruhi keputusan berkunjung wisatawan $(\mathrm{Y})$. 


\section{Gambar 1}

\section{Kerangka Konseptual Penelitian}

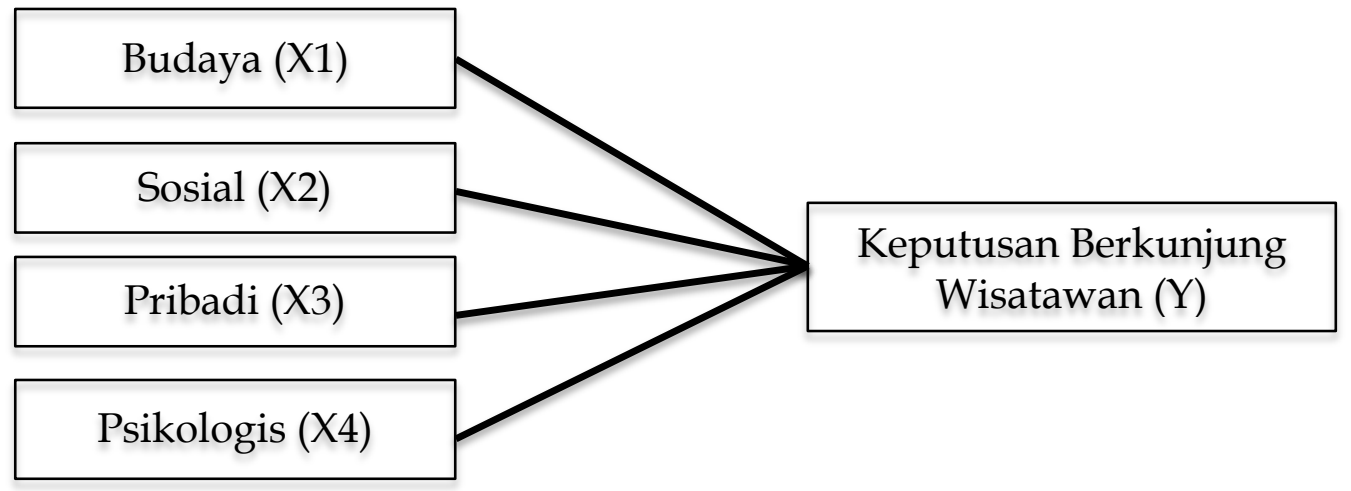

Hipotesis merupakan hubungan yang diperkirakan secara logis di antara dua atau lebih variabel yang diungkapkan dalam bentuk pernyataan yang dapat diuji. Hubungan tersebut diperkirakan berdasarkan jaringan asosiasi yang ditetapkan dalam kerangka teoritis yang dirumuskan untuk studi penelitian (Sekaran dan Bougie, 2013). Mengacu pada pemaparan penelitian terdahulu, maka dapat dijabarkan hipotesis penelitian sebagai berikut:

$\mathbf{H}_{1}$ : Terdapat pengaruh faktor Budaya $(\mathrm{X} 1)$, terhadap keputusan kunjungan wisatawan (Y).

$\mathbf{H}_{2}$ : Terdapat pengaruh faktor Sosial (X2), terhadap keputusan kunjungan wisatawan (Y).

$\mathbf{H}_{3}$ : Terdapat pengaruh faktor Personal (X2), terhadap keputusan kunjungan wisatawan $(Y)$.

$\mathbf{H}_{4}$ : Terdapat pengaruh faktor Psikologi (X2), terhadap keputusan kunjungan wisatawan $(Y)$.

\section{METODOLOGI PENELITIAN}

Jenis penelitian yang digunakan adalah penelitian eksplanatori, seperti penjelasan dari Singarimbun dan Effendi (2006), penelitian eksplanatori adalah penelitian yang menjelaskan mengenai hubungan kausal antara variabel melalui pengujian hipotesis yang telah dirumuskan, sehingga dapat mengetahui seberapa besar kontribusi variabel bebas terhadap variabel terikat serta besarnya arah hubungan yang terjadi. Dalam penelitian kuantitatif, populasi diartikan sebagai wilayah generalisasi yang terdiri atas obyek atau subyek yang mempunyai kualitas dan karakteristik tertentu yang ditetapkan oleh peneliti untuk dipelajari dan kemudian ditarik kesimpulannya". Populasi dalam penelitian ini adalah wisatawan yang mengunjungi Malino Highland, Gowa. Pengambilan sampel dilakukan dengan teknik purposive sampling dan jumlah sampel yang memenuhi kriteria ialah 150 responden.

Penelitian ini menggunakan sumber data primer dan data sekunder. Data primer dalam penelitian ini diperoleh dari jawaban responden. Sumber data sekunder dalam penelitian ini berupa data dari sumber internet mengenai 
perusahaan dan fenomena yang sedang terjadi. Pengumpulan data dalam penelitian ini dilakukan dengan pembagian kuesioner secara online melalui google form dan secara langsung.

Beberapa uji yang dilakukan untuk menganalisis data yang diperoleh dan dikumpulkan. Pertama dilakukan pengeditan data, penanganan respon kosong, pengkodeaan data, pengkategorian data, menyusun arsip data, selanjutnya akan dilakukan uji statistik menggunakan SPSS 22.00 dan Excel. Uji Statistik ini dilakukan dengan beberapa pengujian uji kualitas data, uji asumsi klasik, analisa regresi berganda dan uji hipotesis. Data kuantitatif yang diperoleh menggunakan skala interval atau skala likert yang diperoleh dari daftar pernyataan yang digolongkan ke dalam lima poin.

\section{HASIL DAN PEMBAHASAN}

Penelitian ini menggunakan analisis regresi berganda, sebelum dilakukan analisis ini data telah memenuhi uji kualitas data dan uji asumsi klasik. Hasil ringkasan mengenai analisis regresi berganda dan Uji Hipotesis dalam penelitian ini disajikan dalam Tabel 1.

Tabel 1

Hasil Ringkasan Analisis Regresi Berganda

\begin{tabular}{|c|c|c|c|c|c|c|}
\hline \multirow[b]{2}{*}{ Variabel } & \multicolumn{3}{|c|}{ Beta } & \multirow[b]{2}{*}{ thitung } & \multirow[b]{2}{*}{ Sig. } & \multirow[b]{2}{*}{ Ket } \\
\hline & Unstan & Coefficients & Standardized Coefficient & & & \\
\hline Constant & & & & & & Sig \\
\hline $\mathbf{X}_{1}$ & & & 0,196 & 2,595 & 0,010 & Sig \\
\hline $\mathrm{X}_{2}$ & & & 0,228 & 3,482 & 0,001 & Sig \\
\hline$X_{3}$ & & & 0,179 & 2,420 & 0,017 & Sig \\
\hline$X_{4}$ & & & 0,330 & 4,208 & 0,000 & Sig \\
\hline $\begin{array}{l}\text { Koefisien D } \\
\text { F-Hitung } \\
\text { F-Tabel } \\
\text { Sig.F } \\
\text { t- tabel } \\
\text { a } \\
\text { n (sampel) } \\
\text { Persamaan }\end{array}$ & retermin & $\begin{aligned}2) & =0,521 \\
& =41,507 \\
& =2,434 \\
& =0.000 \\
& =1,976 \\
& =0,05 \\
& =150 \\
& =4,7729+0\end{aligned}$ & $199 X_{1}+0,301 X_{2}+0,154 X_{3}$ & $+0,359 X_{4}$ & & \\
\hline
\end{tabular}

Analisa diatas menunjukan adanya pengaruh secara simultan yang ditunjukan dengan besarnya nilai F hitung $>$ F tabel. Pengaruh Parsial ditunjukan dengan bearnya nilai $t$ hitung setiap variabel lebih besar dari t tabel. Besanya pengaruh variabel bebas ke variabel terikat ditunjukan dengan besarnya Adjusted $\mathrm{R}^{2}$ sebesar 52,1\% dan sisanya sebesar 47,9\% dipengaruhi variabel yang tidak diteliti dalam penelitian ini. Variabel yang berpengaruh paling besar adalah variabel psikologis yang ditunjukan dari besarnya nilai 
koefisien beta.

Hasil analisis menunjukan bahwa kebudayaan, sosial, pribadi dan psikologis secara simultan berpengaruh signifikan terhadap keputusan kunjungan wisatawan. Hasil penelitian menunjukan bahwa keempat variabel bebas memberikan kontribusi terhadap variabel terikat yaitu keputusan pembelian sebesar 52,1\%. Jadi, dalam penelitian ini yang mempengaruhi keputusan pembelian dipengaruhi variabel bebas lain yang tidak diteliti sebesar 47,9\%. Pengaruh signifikansi antara variabel bebas kebudayaan, sosial, pribadi dan psikologis terhadap variabel terikat keputusan pembelian dapat dilihat dari nilai sig F sebesar 0,000 lebih kecil dibandingkan a sebesar 0,05 maka Ho ditolak. Hasil selanjutnya dari penelitian adalah masing-masing variabel kebudayaan $(X 1)$, sosial $(X 2)$, pribadi $(X 3)$, dan psikologis $(X 4)$ berpengaruh signifikan secara parsial terhadap variabel keputusan pemebelian. Hasil tersebut sesuai dengan penelitian yang dilakukan oleh Magdalena, Arsy, Ghoni dan Bodroastuti (2012), serta Okkysantria (2014) yang menunjukan pengaruh masing-masing variabel terhadap keputusan pembelian. Dari hasil keseluruhan dapat disimpulkan bahwavariabel kebudayaan, sosial, pribadi, dan psikologi mempunyai pengaruh yang signifikan terhadap keputusan pembelian secara simultan dan parsial. Dapat diketahui bahwa keempat variabel bebas tersebut yang paling dominan pengaruhnya terhadap Keputusan pembelian adalah Psikologis karena memiliki nilai koefisien beta dan $t$ hitung paling besar. Pengujian variabel dominan dapat diketahui dengan cara melihat hasil koefisien beta (Standardized Coefficients). Uji dominan menunjukan bahwa variabel psikologis (X4) dengan nilai 0,330 merupakan variabel dominan dalam mempengaruhi keputusan kunjungan wisatawan Malino Highland, Gowa. Berdasarkan hasil penelitian menunjukan bahwa variabel psikolosis yang diukur dengan menggunakan empat indikator, yaitu motivasi, persepsi, pembelajaran, serta keyakinan dan sikap konsumen terhadap suatu produk, memiliki pengaruh yang lebih besar daripada ketiga variabel lainnya.

\section{KESIMPULAN DAN SARAN}

Pengaruh secara simultan tiap variabel bebas terhadap keputusan pembelian dilakukan dengan pengujian F-test, yang berarti variabel bebas mempunyai pengaruh yang signifikan secara simultan terhadap keputusan pembelian. Dapat disimpulkan bahwa pengujian terhadap hipotesis yang menyatakan bahwa adanya pengaruh secara bersama-sama (simultan) variabel bebas terhadap variabel terikat yaitu keputusan pembelian dapat diterima. Berdasarkan pada hasil uji $\mathrm{t}$ didapatkan bahwa variabel psikologi mempunyai nilai $\mathrm{t}$ hitung dan koefisien beta yang paling besar. Variabel psikologi mempunyai pengaruh yang paling kuat (dominan) dibandingkan dengan variabel yang lainnya maka variabel psikologi mempunyai pengaruh yang dominan terhadap keputusan pembelian.

Berdasarkan kesimpulan dan hasil penelitian yang ada, dapat dikemukakan beberapa saran yang diharapkan dapat bermanfaat bagi perusahaan maupun bagi pihak-pihak lain. Variabel Kebudayaan menunjukan 
nilai mean terendah adalah indikator sub budaya, dalam penelitian ini item yang digunakan adalah kondisi geografis. Untuk menjangkau Malino Highland, diperlukan kemudahan akses transportasi ketempat ini, dengan cara bekerjasama dengan pihak travel, dan bekerjasama dengan pihak lain yang berhubungan dengan transportasi untuk memperkenalkan wisatawan mengenai tempat ini.

Variabel Sosial memiliki nilai mean yang masih terbilang rendah, yaitu dibawah 4. Hal itu menunjukan kurang kuatnya pengaruh sosial terhadap pengunjung wisata alam. Indikator dalam faktor ini adalah pengaruh teman atau kelompok referensi, keluarga, serta peran dan status. Untuk meningkatkan pengaruh dari variabel ini dapat dilakukan dengan mengadakan sales promotion seperti, paket keluarga atau teman dan membuat iklan dengan melibatkan tokoh penting yang berpengaruh pada wisata alam di Indonesia. Variabel Pribadi menunjukan 2 nilai mean yang masih memiliki nilai di bawah 4 . Nilai mean tersebut adalah indikator dari kondisi ekonomi dan konsep diri. Untuk meningkatkan pengaruh dari variabel ini, perlu dilakukan penetapan harga yang lebih terjangkau oleh konsumen, dan membentuk konsep wisata alam di Indonesia yang lebih menarik seperti membuat konsep musiman yang memiliki jangka waktu tertentu.

Variabel psikologis merupakan variabel paling dominan, dalam variabel ini item motivasi dan persepsi memiliki nilai mean dibawah 4 . Hal tersebut dapat ditingkatkan dengan memperkuat citra merek dari perusahaan. Perusahaan harus memperkuat citra merek bahwa Malino Highland merupakan wisata alam dengan pemandangan yang mempesona. Hal itu dilakukan untuk membentuk motivasi, persepsi, pembelajaran, keyakinan dan sikap konsumen. Saran untuk penelitian selanjutnya, dapat dilakukan dengan menguji variabel lain yang belum diteliti dalam penelitian ini.

DAFTAR PUSTAKA

A. Cohen, Girish Prayag \& Miguel Moital. 2014. Consumer behaviour in tourism: Concepts, influences and opportunities, Current Issues in Tourism, 17:10, 872-909, DOI: 10.1080/13683500.2013.850064

Adhi, Imam Ahmad, Maria Goretti Wi Endang NP, and Pravissi Shanti. "Pengaruh Faktor Psikologis terhadap Keputusan Berkunjung (Survei Pada Pengunjung Batu Secret Zoo Jawa Timur Park 2)." Jurnal Administrasi Bisnis 30.1 (2016): 35-43.

Arida, N. K. 2009. Meretas Jalan Ekowisata Bali Proses Pengembangan, Partisipasi Lokal dan Tantangan Ekowisata di Tiga Desa Kuno Bali. Denpasar: Udayana University Press.

Arikunto, Suharsimi., 2010, Prosedur Penelitian Suatu Pendekatan Praktik, Ed. rev, Rineka Cipta, Jakarta.

Arsy, Rakhmat Mokhtar An., 2012, Pengaruh Faktor Budaya, Soaial, Pribadi dan Psikologis Konsumen terhadap Keputusan Pembelian Motor Matic Yamaha. (Study kasus pada PT. Tunas Kencana Data Bekasi).

Correia, A. dan G. I. Crouch. 2008. A Study of Decision Processes. Andi. Yogyakarta.

Diamantis, D. 2004. Ecotourism: Management and Assesment. London: 
Thomson Learning.

Ghozali, Imam., 2011, Aplikasi Analisis Multivariate dengan Program IBM SPSS 19, Badan Penerbit Universitas Diponegoro, Semarang.

http://makassar.tribunnews.com/2018/01/31/234706-wisatawan-kunjungi-objekwisata-di-gowa-selama-2017 (Diakses 18 Mei 2018)

Kotler, Philip., dan Gary Armstrong., 2012, Principles of Marketing, 14th Ed, Prentice Hall, Jakarta.

Magdalena, Pipit Amelia., 2012, Pengaruh Budaya, Sosial, Pribadi dan Psikologis Terhadap Proses Keputusan Pembelian Susu Formula Anak (Balita) di Kota Malang, Skripsi Fakultas Ekonomi dan Bisnis Universitas Brawijaya, Malang, Jurnal Skripsi FEB UB.

Mondal, S. 2015. Tourists SPOT Buying Behavior: An Analytical Study. Journal of Tourism \& Hospitality, 2015.

Morrison, A. 2008. Hospitality and Travel Marketing. Edisi Kelima. Ahli Bahasa Sulistiyani. Salemba Empat. Jakarta.

Oetarjo, Mas. "Pengaruh Prilaku Konsumen Terhadap Minat Berkunjung ke Wisata Bahari Lamongan." Fakultas Ekonomi Universitas Muhammadiyah Sidoarjo (2013).

Okkysantria, Dyca., 2014, Analisis Pengaruh Kebudayaan, Sosial, Pribadi Dan Psikologis Konsumen Usia Muda Terhadap Keputusan Pembelian Makanan Cepat Saji Mcdonald's (Studi Pada Konsumen Mcdonald's Watugong Malang), Jurnal Skripsi FEB UB.

Omondi, S. 2017. Determinants of Consumer Buying Behaviour for The Domestic Tourists in Kenya. Tesis United States International University Africa. Diakses 20 Maret 2018.

Rahman, Muh. Akil. (2016, June). Pengaruh Penggunaan Media Sosial Terhadap Keputusan Pembelian Lewat Internet di Kalangan Mahasiswa. In Assets (Vol. 6, No. 1, pp. 103-115).

Rahman, Muh. Akil., \& Taning, M. (2015). Pengaruh Customer Relationship terhadap Loyalitas Pelanggan pada PT. BANK Mandiri (Persero) Tbk Cabang Cokroaminoto Makassar. Jurnal Manajemen Ide dan Inspirasi, 2(2), 50-67.

Sekaran, U. and Bougie, R. 2013. Research Methods for Business A Skill-Building Approach. 6th Edition, Wiley, New York.

Urfana, Millatina., dan Sembiring, Beby Karina Fawzeea., 2012, Analisis Pengaruh Faktor Kebudayaan, Sosial, Pribadi, Dan Psikologis Terhadap Keputusan Pembelian Makanan Cepat Saji Pada Konsumen Kentucky Fried Chicken (KFC) Walikota Medan. 